\title{
ARE MARKETS ADAPTIVE? EVIDENCE OF PREDICTABILITY AND MARKET EFFICIENCY OF LODGING/RESORT REITs
}

\author{
Fahad ALMUDHAF ${ }^{1}$, Ramya Rajajagadeesan AROUL ${ }^{2, *}$, J. Andrew HANSZ ${ }^{3}$ \\ ${ }^{1}$ Department of Finance and Financial Institutions, Kuwait University, P.O. Box 5486, Safat 13055, Kuwait \\ ${ }^{2}$ Department of Accounting and Finance, Texas A\&M University-Commerce, Commerce, TX 75429, USA \\ ${ }^{3}$ Department of Finance and Real Estate, University of Texas at Arlington, Arlington, TX 76019, USA
}

Received 24 January 2019; accepted 05 September 2019

\begin{abstract}
We investigate the degree of return predictability of lodging/resort real estate investment trusts (REITs) from January 1994 to May 2016. We test the Martingale hypothesis by using linear (automatic portmanteau and automatic variance ratio with rolling windows) and nonlinear tests (generalized spectral shape tests and Dominguez-Lobato consistent tests). Our findings support the Adaptive Market Hypothesis (AMH) and reveal that returns experience periods of both dependence and independence. We document time-varying predictability of lodging/resort REITs with returns as both initially predictable and subsequently unpredictable throughout the majority of the period of analysis. Moreover, we find that if traders use simple technical trading moving average rules, they can capitalize on the inefficiencies of lodging/resort REITs. Finally, we observe that absolute returns and Sharpe ratios of technical moving average rules outperform a simple buy-and-hold strategy.
\end{abstract}

Keywords: lodging REIT, Adaptive Markets Hypothesis, market efficiency, return predictability, nonlinear tests, technical trading.

\section{Introduction}

Efficient Market Hypothesis (EMH) in its weak-form implies that current market prices instantaneously and comprehensively reflect historical information (Fama, 1970, 1991). In an efficient market, returns are unpredictable and are independent with no autocorrelation. Yen and Lee (2008) chronologically survey and review the literature on $\mathrm{EMH}$ and find that it has less empirical support compared to literature from the earlier three decades. Alternatively, Lo's Adaptive Market Hypothesis (AMH), derived from evolutionary psychology, is gaining popularity in financial economics (Lo, 2004, 2005). AMH is based on the concept of relative efficiency and is a novel framework that merges EMH with behavioral alternatives by applying the Darwinian principles of evolution - like adaptation, competition, and natural selection - to capital markets. Lo's 2004 study extends the notion of Herbert Simon's "satisficing" with evolutionary characteristics, and finds that market efficiency, along with return predictability, can be dynamic and vary with time (Simon, 1955, 1982). Changing market conditions can occasionally cause predictable asset prices. However, market efficiency is not binary (0 or 1$)$ as it evolves with variations in the underlying market fac- tors. For example, regulatory or institutional changes may influence the efficiency of asset markets.

As explained by Oak and Andrew (2003), market efficiency is important to hotel investors, especially during the valuation and appraisal process of hotel properties. In an efficient market, investors have similar and proper access to information. Therefore, prices reflect a market based on shared information, as opposed to a market in which some users may unfairly access historical data to better predict the future. Investors implicitly assume market efficiency by applying valuation methods to the use of hotel data such as occupancy rates, Average daily rate (ADR), capitalization rates, and expectations of supply and demand are caused by economic or market conditions (Oak \& Andrew, 2003).

Real estate investment trusts' (REITs hereafter) subsectors behave differently from one another and therefore, deserve separate evaluation (Block, 2012). As a hybrid of both retail and housing, lodging/resorts are unique assets in nature. As of April 2016, lodging/resort REITs have a market capitalization of $\$ 41$ billion, according to NAREIT. ${ }^{1}$ Lodging/resort REITs are viewed as aggressive

1 https://www.reit.com/sites/default/files/returns/FNUSIC2016.pdf

${ }^{*}$ Corresponding author. E-mail: ramya.aroul@tamuc.edu 
investments because of their cyclicality and volatile room and occupancy rates. The demand for U.S. lodging is more closely correlated to the U.S. GDP and economy than any other property subsector. U.S. lodging exhibits high cyclic behavior (Wheaton \& Rossoff, 1998).

Compared to other types of REIT subsectors, lodging/ resort REITs have the highest volatility and the highest market risk, as shown by Ro and Ziobrowski (2011) and Kim, Mattila, and Gu (2002b). The vast majority of total risk for hotel REITs (about $84 \%$ ) is uniquely firm-specific, while the remaining percentage of risk arises from market factors (Kim, Gu, \& Mattila, 2002a; Gu \& Kim, 2003). Both Kim et al. (2002b) and Jackson (2009) find that lodging/ resort REITs underperform other REIT subsectors after adjusting for risk. However, in a later article, Kim, Jackson, and Zhong (2011) demonstrate that lodging REITs have lower volatility compared to stocks, and recommends adding lodging REITs to investment portfolios for diversification purposes. Tang and Jang (2008) and Kim and Jang (2012) find that the profitability and performance of hotel REITs are similar to that of hotel C-corporations, despite their different organizational characteristics and taxation. Payne (2006) find that the lodging subsector has the highest initial response to shocks and innovations, which are transmitted from other REIT subsectors. In a subsequent study, Payne and Waters (2007), show that lodging is the only REIT subsector to exhibit behavior consistent with periodically collapsing bubbles. Lodging REITs have a higher trading volume, both before and after- the financial crisis of 2008, compared to other subsectors (Jain, Robinson, Singh, \& Sunderman, 2017). These findings motivate us to dig deeper into research regarding the lodging REIT subsector.

Feng, Price, and Sirmans (2011) provide a comprehensive comparison of equity REIT subsectors, as well as an analysis of their trends and differences from 1993 to 2009. This comparison shows that the lodging subsector has irregular and fluctuating dividend payout ratios during the sample period; lodging has the highest FFO yield and the highest expense ratio compared to the other subsectors studied. In comparison to other real estate market subsectors, lodging also has the lowest ROA, ROE, profit margin, and Tobin's Q. Interestingly, Feng et al. (2011) show an increase in institutional ownership in the lodging subsector, from $21 \%$ in 1993 to $58 \%$ in 2009 .

Recently, there is considerable interest in studying the lodging/resort real estate market. Both the pricing and performance of domestic and international commercial real estate assets have been extensively examined. While an abundance of studies examine commercial property asset classes - like offices, apartments, and retail properties -relatively few studies investigate the lodging/resort property markets. We explicitly test the predictability and efficiency of the less-examined lodging/resort real estate market. It is necessary that we first investigate and identify the market efficiency of the lodging subsector so that we can see how the results of general real estate markets apply to the hotel market.
To conduct our research, we use moving subsample, fixed window intervals in applied linear (automatic variance ratio and automatic portmanteau tests) and nonlinear tests to measure the level of return predictability. Our findings indicate that the extent of market efficiency in lodging/resort REITs changes over time, which supports the implications of the AMH discussed by Lo $(2004,2005)$. We also find clear evidence of nonlinear dependency in lodging/resort REITs. Our study contributes to the finance and lodging literature because it examines the evolving efficiency and predictability of the under-researched lodging/resort REIT subsector explicitly, as explored by Liu (2010) and Manning et al. (2015).

According to the Adaptive Market Hypothesis (AMH), investors occasionally find arbitrage opportunities. Therefore, we apply technical trading rules to lodging/resort REITs and conclude that mispricing and inefficiency generated return opportunities that are greater than transaction costs. We also find that absolute returns and Sharpe ratios of moving average technical rules outperform a naive buy and hold strategy. Our research reveals the presence of economically exploitable opportunities where economic benefits exceed transaction costs. Our results will interest and assist investors who continually seek arbitrage opportunities and market inefficiencies to create trading strategies to generate abnormal profits.

\section{Literature review}

The concept of market efficiency has extensively been used in the pricing of financial securities. EMH defines an efficient market as one in which trading on available information fails to provide an abnormal return (Fama, 1970). Psychologists and behavioral economists question and critique the primary assumption of rational investors, as well as the premise of complete and instantaneous information absorption, and contend that these suppositions do not reflect fundamental human behavior.

However, recent advances in evolutionary psychology and cognitive neurosciences potentially reconcile EMH with behavioral anomalies (Lo, 2007). Simon's 1955 and 1982 works developed and popularized the concept of bounded rationality. Bounded rationality postulates that cognitive limitations potentially restrict peoples' decisions. Most often, people act as satisficers and seek a satisfactory solution rather than an optimal and rational answer. Lo (2004) extends Simon's concept of satisficing by using evolutionary dynamics and offers a new framework called the Adaptive Markets Hypothesis (AMH). Brennan and Lo (2011) later create a binary period model for AMH. Several recent studies provide empirical evidence in support of AMH in stock markets (e.g., Kim, Shamsuddin, \& Lim, 2011; Urquhart \& Hudson, 2013; Ghazani \& Araghi, 2014; Almudhaf, 2017), foreign exchange (e.g., Charles, Darné, \& Kim, 2012), and precious metals' markets (e.g. Charles, Darné, \& Kim, 2015).

Prior studies of market efficiency in real estate literature exhibit few contradictions. Numerous studies test 
market efficiency in real estate (Gau, 1984, 1985; Rayburn, Devaney, \& Evans, 1987; McIntosh \& Henderson, 1989; Case \& Shiller, 1989). Gau (1984) documents the presence of weak-form market efficiency in the Canadian residential market, while Hamilton and Schwab (1985) find that the U.S. market is inefficient. Later studies like Case and Shiller (1989, 1990), Wang (2004), and Kummerow and Lun (2005) also find evidence of a lack of weak-form market efficiency in housing markets. Studies that examine market efficiency in commercial property markets also find contradicting results. McIntosh and Henderson (1989) find evidence of market efficiency in office markets, while Barkham and Geltner (1995) and Liu and Mei (1992) find office markets to be informationally inefficient.

Several papers have also examined the efficiency and predictability of REITs (e.g., Cabrera, Wang, \& Yang, 2011; Huang, Su, \& Chiu, 2009; Jirasakuldech \& Knight, 2005; Kleiman, Payne, \& Sahu, 2002; Kuhle \& Alvayay, 2000; Serrano \& Hoesli, 2010; Schindler, Rottke, \& Fuss, 2010; Schindler, 2011; Su, Cheung, \& Roca, 2012). These studies use different methodologies to examine national and international markets during different periods with different data frequencies. While Kleiman et al. (2002) and Jirasakuldech and Knight (2005) provide some evidence of efficiency in REITs, most of the literature on REIT efficiency find these markets to be informationally inefficient (Kuhle \& Alvayay, 2000; Huang et al., 2009; Schindler et al., 2010).

Schindler (2011) studies 12 emerging and four developed and securitized real estate markets from 1992 through 2009 and documents that the weak form EMH is not rejected by any in seven of the 12 markets. Cabrera et al. (2011) examine the short-horizon return predictability of the ten largest internationally securitized real estate markets and find evidence of inefficiency in many internationally securitized real estate markets. Su et al. (2012) also find that real estate markets are relatively less efficient compared to stock and bond markets.

In their study, Zhou, and Lee find market efficiency in the REIT market and that the degree of predictability decline over time (Zhou \& Lee, 2013). As indicated in Jang and Park (2011), there is an increased interest in finance research that focuses on the hospitality discipline. Consequently, we extend and complement the work of Zhou and Lee (2013), which investigates the AMH of the value-weighted, all-REIT index, using data from CRSP/ Ziman Real Estate between the years 1980 and 2009. They document that market efficiency is not an all-or-none condition but varies continuously over time. They also show that market efficiency is dependent upon market conditions. While Zhou and Lee (2013) examines the overall REIT market, our study specifically addresses these questions for the lodging REIT sector. Similar to their study, we employ the automatic variance ratio test of Choi (1999), and the automatic portmanteau test of Escanciano and Lobato (2009) and find that both their implications for the US REIT market holds for the lodging REIT sector as well. The degree of REIT return predictability is also found to be time varying. Our results are generally similar to that of Zhou and Lee (2013) implying that the lodging/ resort REIT market more or less behaves like the overall US REIT market.

Although many studies have examined the presence of market efficiency in real estate markets (with conflicting results), few have focused on lodging/resort properties. Oak and Andrew (2003) use autocorrelation and cross-correlation analyses to test for weak-form market efficiency in hotel real estate markets. They use the Hospitality Valuation Index (HVI) from 1987 to 1999 and find evidence supporting weak-form efficiency. Bloom (2009) documents a significant difference in the betas of up, flat, and down markets by using the historical beta as the predictor of hotel stocks' performance. Mar-Molinero, Menéndez-Plans, and Orgaz-Guerrero (2017) examine the determinant of beta and uncover that the financial crisis of 2008 affected the factors of systematic risk in the European hospitality industry. Moreover, numerous studies apply the event-study methodology to test for a semi-strong form of market efficiency in hospitality stocks (e.g., Borde, Byrd, \& Atkinson, 1999; S. H. Kim, W. G. Kim, \& Hancer, 2009; Koh \& Lee, 2013; Lee \& Connolly, 2010).

This paper contributes to the relatively thin stream of work on market efficiency in the lodging industry. Oak and Andrew (2003) examine the market efficiency of the HVI index to assess the primary hotel asset market and track the hotel value changes. Our study differs from theirs in many ways. Using autocorrelation and cross-correlation analysis, Oak and Andrews (2003) finds evidence supportive of weak-form market efficiency in the hotel market. They also document that buy-and-sell trading strategies using prior returns do not earn higher returns than buyand-hold strategies. They use the Hospitality Valuation Index (HVI) from 1987 to 1999 to test the hypotheses while our study uses the monthly price index of FTSE/ NAREIT lodging/resort REIT subsector. The HVI is based on product market information like room occupancy and rate while we use market price indices reflecting the capital market performance. Since we examine the efficiency of the secondary market by tracking the lodging REITs' index, we provide another dimension to the importance of efficiency from an owner's perspective. Our study not only seeks to examine the efficiency of hotel REITs market but also extends the time span to the 2000s. In addition to these differences, we also employ robust methods including Wild Bootstrap Automatic Variance Ratio, Automatic Portmanteau Test, Generalized Spectral Shape Test and Dominguez and Lobato (2003) consistent test that allows us to explore the changing market efficiency conditions in comparison to autocorrelation and cross-correlation analyses employed by Oak and Andrews (2003).

Prior studies on efficiency use methods that provided a binary output which would indicate if the market was efficient. We use a dynamic, nonlinear approach to account for Lo's (2004) concept of evolving market efficiency rather than being a binary 0 or 1 , which enable us to identify the 
time-varying efficiency of the market over a long period. Moreover, we also use AMH, an evolutionary concept, to explain the time-varying nature of market efficiency.

\section{Data and methodology}

We use the monthly price index of FTSE/NAREIT lodging/resort REIT subsector ${ }^{2}$ to complete our analysis. This index is a free-float ${ }^{3}$ adjusted market, capitalizationweighted index that includes all tax-qualified REITs listed on the NYSE, AMEX, and the NASDAQ National Market. The weight of each lodging REIT is based on the market cap of that REIT relative to the total market cap of all the listed lodging REITs. In our data, the larger lodging REITs (e.g., Host Hotels \& Resorts, Hospitality Properties Trust, and Apple Hospitality REIT Inc.) have more weight in the index than compared to the smaller lodging REITs (e.g., Condor Hospitality Trust, InnSuites Hospitality Trust, and Sotherly Hotels Inc.). Our use of monthly frequency is based on data availability. The number of constituents in the index is not constant through time.

As of May 2016, the components of the index include 20 lodging/resort REITs, for a total market capitalization of \$40 billion (Appendix Table A1), and we use all data available since the inception of the index. The data spans from January 1994 to May 2016, and the returns were calculated as the first logarithmic difference of the price index. To address the data snooping bias ${ }^{4}$, we use a fixed-length rolling window of three years for the subsamples, which allows for better detection of short-lived periods of return predictability. We start with the first subsample and implement the tests again, moving forward one month at a time to the next subsample; we repeat this procedure until the end of the sample.

\subsection{Wild Bootstrap Automatic Variance Ratio (AVR)}

The variance ratio estimator is

$$
\widehat{V R}(L)=1+2 \sum_{1}^{T-1} k\left(\frac{i}{L}\right) \hat{\rho}(i)
$$

were: $\hat{\rho}(i)=\int_{t=1}^{T-i} \Delta r_{t} \Delta r_{t+i} / \sum_{t=1}^{T} \Delta r_{t}^{2}$, and

$$
k(x)=\frac{25}{12 \pi^{2} x^{2}}\left[\frac{\sin \left(\frac{6 \pi x}{5}\right)}{\frac{6 \pi x}{5}}-\cos \left(\frac{6 \pi x}{5}\right)\right] .
$$

2 Historical monthly data is available from https://www.reit.com/ sites/default/files/returns/Lodging-Resorts.xls

3 Free-float does not include all REITs outstanding shares. It includes only actively readily available stocks for trading and excludes stocks held by insiders, governments, and locked-in shares.

4 Data-snooping is also known as data fishing or data dredging. When reusing the same data, it is possible that significant results are due to luck and generated by chance and not due to the method used.
Choi (1999) developed a data dependent method for optimally choosing $L$. The variance ratio is estimated with the Quadratic Spectral kernel. We select the truncation point to optimally test the null hypothesis of the absence of serial correlation. The standardized statistic is,

$$
A V R=\frac{\sqrt{T}}{L[\widehat{V R}(L)-1]} / \sqrt{2} .
$$

We use a wild bootstrap for the automatic variance ratio test to improve the power properties of the test, as suggested in Kim's 2009 study.

\subsection{Automatic Portmanteau test}

We use a Box-Pierce test for the data-driven serial correlation of Escanciano and Lobato (2009). The test automatically selects the order of the autocorrelation tested by selecting whether the Akaike information criterion (AIC) or Bayesian information criterion (BIC) is used to determine the order of autocorrelation. We discover that it is robust to conditional heteroskedasticity. The robustified Portmanteau statistic is

$$
A Q=Q_{p}^{*}=n \sum_{j=1}^{p} \tilde{\rho}_{j}^{2},
$$

where: $\tilde{\rho}_{j}^{2}=\frac{\hat{\gamma}_{j}^{2}}{\hat{\tau}_{j}}$ and $\hat{\tau}_{j}=\frac{1}{n-j} \sum_{t=1+j}^{n}\left(Y_{t}-\bar{Y}\right)^{2}\left(Y_{t-j}-\bar{Y}\right)^{2}$ was the sample analog of $\tau_{j}=E\left(Y_{t}-\mu\right)^{2}\left(Y_{t-j}-\pi\right)^{2}$.

\subsection{Generalized spectral shape test}

Escanciano and Velasco (2006) use the generalized spectral distribution function to test for serial dependence and the martingale difference hypothesis (MDS); the test captures nonlinear dependence.

$$
\hat{H}(\tau, x)=\hat{\gamma}_{0}(x) \tau+2 \sum_{j=1}^{n-1}\left(1-\frac{j}{n}\right)^{1 / 2} \hat{\gamma}_{j}(x) \frac{\operatorname{sinj} \pi \tau}{j \pi} .
$$

To test the null hypothesis $H_{0}$, Escanciano and Velasco utilizes this process

$$
\begin{aligned}
& S_{n}(\tau, x)=\left(\frac{n}{2}\right)^{1 / 2}\left\{\hat{H}(\tau, x)-\hat{H}_{0}(\tau, x)\right\}= \\
& \sum_{j=1}^{n-1}(n-j)^{\frac{1}{2}} \hat{\gamma}_{j}(x) \frac{\sqrt{2} \sin j \pi \tau}{j \pi} .
\end{aligned}
$$

Escanciano and Velasco (2006) considers the Cramervon Mises norm along with the standard normal random variable to obtain their test statistic,

$$
\begin{aligned}
& D_{n}^{2}=\sum_{j=1}^{n-1}(n-j) \frac{1}{\left(j \pi^{2}\right)} \sum_{t=j+1}^{n} \sum_{s=j+1}^{n}\left(Y_{t}-\bar{Y}_{n-j}\right)\left(Y_{s}-\bar{Y}_{n-j}\right) \times \\
& \exp \left(-0.5\left(Y_{t-j}-Y_{s-j}\right)^{2}\right) .
\end{aligned}
$$

We find that it is not necessary to choose the lag order or to formulate a parametric alternative when using this test. 


\subsection{Dominguez and Lobato (2003) consistent test}

Dominguez and Lobato base their 2003 study on the Kolmogorov-Smirnov (KS) and the Cramer-von Mises (CvM) test statistics (Dominguez \& Lobato, 2003). They propose a nonlinear measure of dependence to test the martingale difference hypothesis (MDS) as follows:

$$
\begin{aligned}
& K S_{\tilde{p}, n}=\max _{i=1, \ldots n}\left|\frac{1}{\sqrt{n}} \sum_{j=1}^{n}\left(y_{j}-\bar{y}\right) I\left(\tilde{z}_{j, \tilde{p}} \leq \tilde{z}_{i, \tilde{p}}\right)\right| ; \\
& C v M_{\tilde{p}, n}=\frac{1}{n^{2}} \sum_{j=1}^{n}\left[\sum_{t=1}^{n}\left(y_{j}-\bar{y}\right) I\left(\tilde{z}_{t, \tilde{p}} \leq \tilde{z}_{j, \tilde{p}}\right)\right]^{2},
\end{aligned}
$$

where: $p$ is a positive integer (Dominguez \& Lobato, 2003). Dominguez and Lobato (2003) obtain the $p$-value by using a wild bootstrap distribution, which checks for an infinite number of orthogonality conditions. Therefore, there is no need for the user to select the tuning parameters, which is considered an advantage over other methods.

\subsection{Technical trading strategies}

Schindler et al. (2010) and Schindler (2011) compare the buy-and-hold strategy to technical trading moving average rules to test the possibility of capitalizing on the inefficiencies of lodging/resort REITs. Investors consider an index moving average that breaks from the top down a



b)

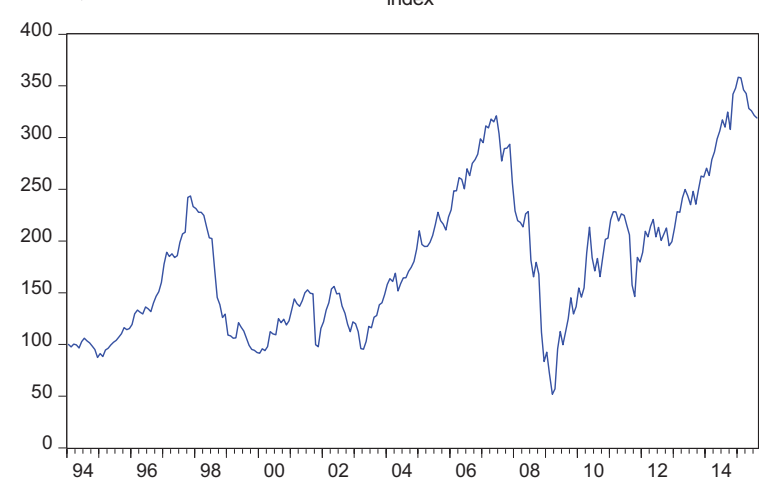

Figure 1. NAREIT lodging/resort Index: a) Time series plots of lodging/resort monthly returns; b) NAREIT lodging/resort subsector over the period from January 1994 to May 2016
Table 1. Summary statistics

\begin{tabular}{|l|c|}
\hline Mean & 0.0036 \\
\hline Median & 0.0059 \\
\hline Minimum & -0.4069 \\
\hline Maximum & 0.5159 \\
\hline Standard Deviation & 0.0874 \\
\hline Coefficient of Variation & 24.1850 \\
\hline Skewness & -0.5075 \\
\hline Excess Kurtosis & 8.0687 \\
\hline
\end{tabular}

'sell' signal. In contrast, investors regard an index moving average as a 'buy' signal when it breaks from the bottom up. We assume that there was no short selling with a $0.1 \%$ transaction cost, per transaction. We use the Sharpe Ratio to control for differences in risk in our comparisons of the buy and hold strategy and the technical trading rules.

\section{Results}

We interpret the descriptive statistics in Table 1 as an indication that the monthly returns of lodging/resort REITs were leptokurtic (positive excess kurtosis) with fat tails. We also find that the distribution exhibited negative skewness (left-skewed), which indicates that the frequencies of negative returns are higher than those of positive returns. Our findings of the Doornik-Hansen normality test statistic reject the null hypothesis of the normal distribution of monthly lodging/resort REIT returns, culminating at a significance level of $1 \%$. Institutional investors have been attracted to lodging/resort REITs since the Revenue Reconciliation Act of 1993 because of their diversification benefits and their hedge against inflation. Figure 1 shows an upward trend in the prices of lodging/resort REITs from 1994 to 1998, as well as sharp declines.

Additionally, there is a market correction from 1998 to 2000 as well as during the 2007-2008 financial crisis. Events such as geopolitical turmoil, wars, terrorist attacks, economic recessions, and uncertainty undoubtedly influence the performance of lodging/resort REITs. The financial crisis caused the industry to suffer from lower demand and high energy prices. Moreover, the time series plot of lodging/resort REIT returns that we exhibit in Figure 1 shows a phenomenon of volatility clustering (substantial changes, both positive and negative, clustering together); this is similar to Zhou and Lee's 2013 results for overall equity REITs (Zhou \& Lee, 2013).

In an efficient market, each successive return is independent; however, this is not what we find in our analysis period. Our study shows that there are years in which the markets are inefficient. We display the automatic variance ratio (AVR) statistic along with a $95 \%$ confidence band in Figure 2. The AVR statistic is in the rejection region from 1997 to 2001, and again in 2005, although only for a short time, before reverting to the $95 \%$ confidence band. We see an apparent drop in predictability after 2005, which 
we show in Figure 3. We also see an ultimate fluctuation in the degree of market efficiency; this is similar to Zhou and Lee's results for equity REITs in general (Zhou \& Lee, 2013).

The horizontal line represents the critical value of test statistic at $5 \%$ which equals 3.84 .

We display the output of the automatic portmanteau test $(\mathrm{AQ})^{11}$ and the oscillatory behavior of both dependency and independency in lodging/resort REIT returns in Figure 3. In these results, we find substantial evidence of predictability during the periods 1998 to 2000, 2003 to 2005, and in 2015. Our AQ statistic indicates that lodging/ resort REIT returns are unpredictable during other periods. Our findings are in line with the AMH in Lo's research $(2004,2005)$, as market efficiency varied over time.
We plot the $p$-values of the GSS test statistic from Escanciano and Velasco (2006) in Figure 4. We examine the $p$-values of the test statistic and infer that the return predictability occurs whenever the $p$-values are below the broken horizontal line. We identify episodes of statistically significant return predictability when the lodging/resort REIT subsector show non-martingale behavior. The return predictability is significant at the $5 \%$ or $10 \%$ level as long as it is less than 0.05 or 0.1 . We find that lodging REITs deviate from the martingale in 1997, 2000, and from 2004 to 2016, as shown in Figure 4. We report the p-value of the DL test from Dominguez and Lobato (2003) and show extended periods of return predictability in Figure 5. We uncover a non-martingale episode between 1999 and 2016. Our tests reject the martingale difference hypothesis for lodging/resort REITs.

AVR statistics and $95 \%$ confidence intervals

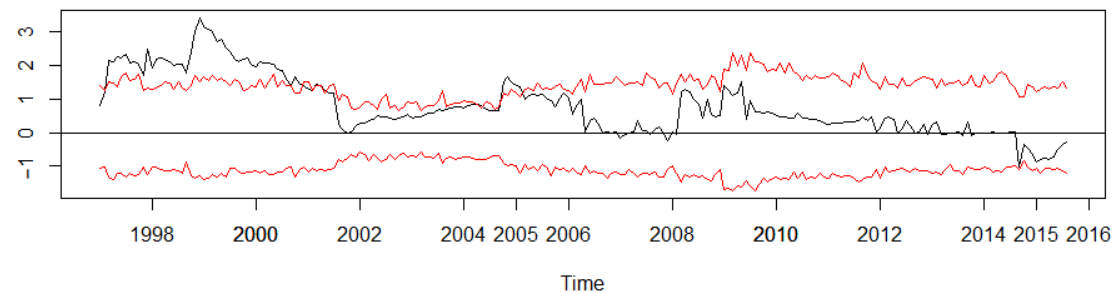

Figure 2. Evolution of Automatic Variance Ratio (AVR) statistic with subsample window of 3 years

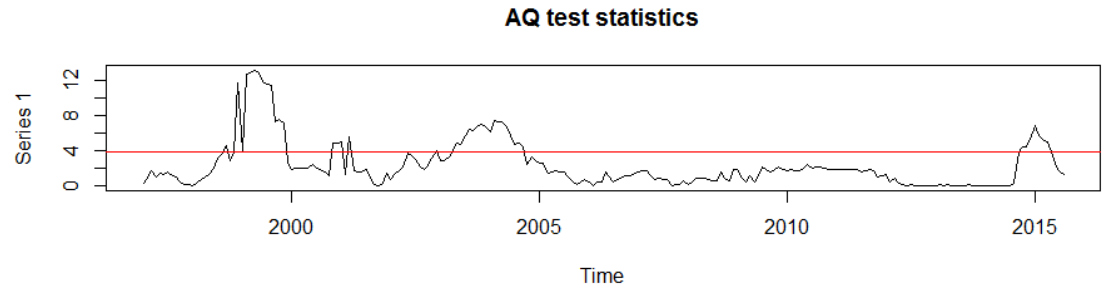

Figure 3. Evolution of Automatic Portmanteau (AQ) statistic with a 3-year rolling window

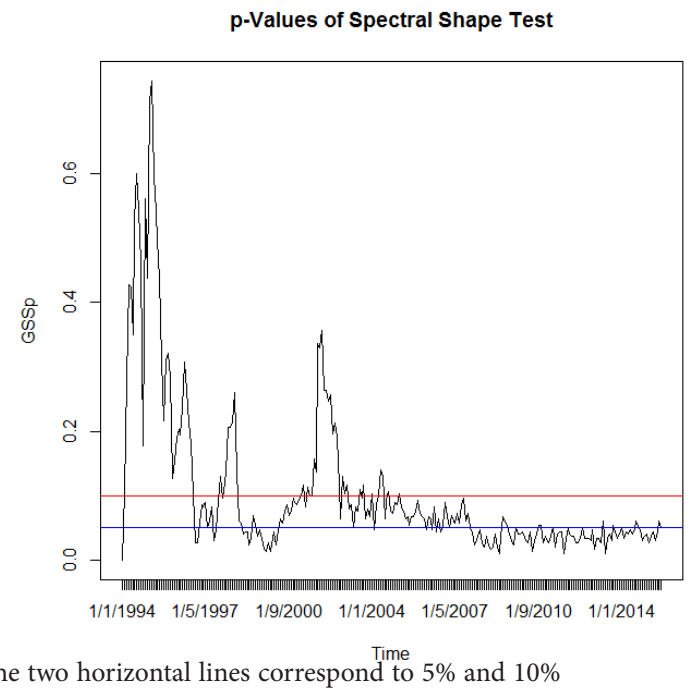

Note: The two horizontal lines correspond to $5 \%$ and $10 \%$

Figure 4. Results of the Spectral Shape GSS test of Escanciano and Velasco (2006)

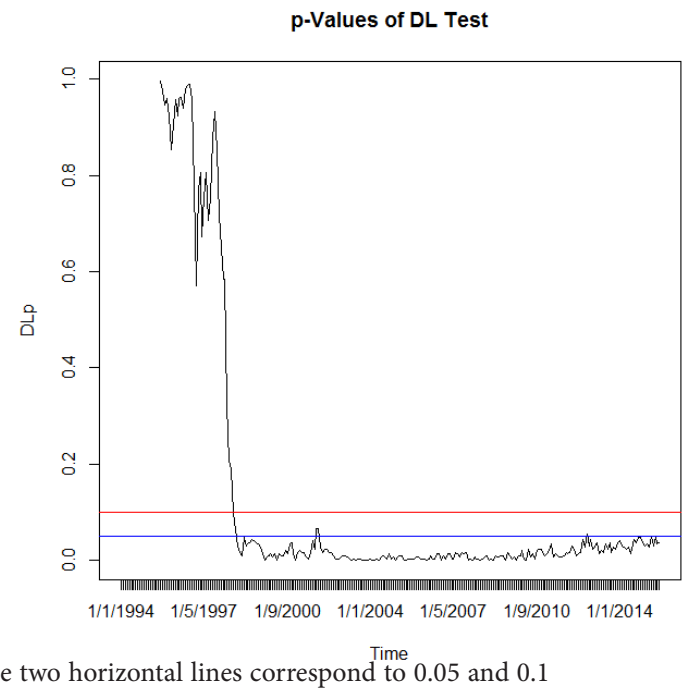

Figure 5. Results of the DL test of Dominguez and Lobato (2003) 
Table 2. Performance of buy-and-hold strategy compared to technical trading strategy based on Moving Averages (MA)

\begin{tabular}{|l|c|c|}
\hline \multicolumn{1}{|c|}{ Strategy } & Annual return & Sharpe Ratio \\
\hline Buy and hold & $4.56 \%$ & 0.07 \\
\hline 3 Months MA & $9.03 \%$ & $0.39^{\star}$ \\
\hline 6 Months MA & $9.53 \%$ & $0.32^{\star}$ \\
\hline 9 Months MA & $12.09 \%$ & $0.48^{\star}$ \\
\hline 12 Months MA & $11.55 \%$ & $0.44^{\star}$ \\
\hline MA 3 \& MA 6 & $9.94 \%$ & $0.35^{\star}$ \\
\hline MA 3 \& MA 9 & $11.19 \%$ & $0.41^{\star}$ \\
\hline MA 3 \& MA 12 & $8.38 \%$ & $0.26^{\star}$ \\
\hline
\end{tabular}

Note: We follow the procedure of Gibbons, Ross, and Shanken (1989) in calculating $W$ statistic, $W$-modified to test the null hypothesis that: Sharpe Ratio $_{i}=$ Sharpe Ratio .

* indicates that the trading strategy is superior to the buy-and-hold strategy with $5 \%$ significance.

We find that portfolios that apply technical analysis rules outperform the buy-and-hold strategy in both absolute and risk-adjusted terms; this remains true when we compared a buy-and-hold strategy to moving average trading rules, as shown in Table 2. We discover that the Sharpe Ratios of the trading strategies are significantly higher and better than those of the buy-and-hold naïve portfolio. We interpret this as evidence against market efficiency and a random walk. Our results are consistent with Glabadanidis (2014); when we apply moving average rules and we find that lodging/resort REITs has the highest alpha, even when we use multiple factors to adjust for risk. This finding indicates that the lodging/resort market is weak-form inefficient (Glabadanidis, 2014).

\section{Discussion and limitations}

In an efficient market, the market value of hotel REITs should reflect and be equal to the value of the sum of its underlying asset holdings (hotels). Markets are considered informationally inefficient if there is a significant deviation between the intrinsic value (fair value) and the market price. Our results are of particular interest to investors who continuously seek market anomalies and arbitrage opportunities to develop trading strategies to yield abnormal profits. We also recommend that investors adopt different investment strategies and plan to address changes based on the levels of market predictability. Investors should not continue using similar asset allocation during all market conditions. Passive investing makes the most sense during periods of market efficiency; mainly when it is difficult to predict the market. On the other hand, market timing is potentially profitable only when markets are temporarily inefficient, enabling investors to exploit informational efficiencies to generate abnormal returns actively.

Profit opportunities can exist as long as lodging REIT markets are both liquid and actively traded. Such opportunities will disappear once they are exploited. However, other possibilities will arise as market participants change, and shifts in the market and regulatory conditions impact the flow of information.

Our study is limited because we only use U.S. lodging/resort indices, so our results should not be generalized and applied to internationally developed or emerging markets. Also, we do not use firm-characteristics of lodging REITs, such as size or institutional ownership, to split our sample and re-examine efficiency differences between different groups of lodging REITs. Other researchers could examine the determinants of market efficiency by using financial characteristics from a sample of lodging REITs. This opportunity is left for future research. Also, the next logical step in this stream of work is providing economic reasoning for the different changing states of market inefficiencies in the loging REITs market.

\section{Conclusions}

Prior studies on the efficiency of real estate markets find that different market sectors have varying degrees of market efficiency (Gatzlaff \& Tirtiroğlu, 1995). These studies focus on various real estate subsectors, including both the primary and secondary residential and commercial markets, and find contradictory results. The findings in the existent literature on commercial property markets do not provide conclusive evidence of market efficiency. Even though several studies inspected other commercial real estate classes, few studies examine the hospitality real estate market. The literature on the market efficiency of the lodging industry is relatively thin. Oak and Andrew (2003) provide initial evidence of market efficiency in the primary hotel asset market by using the HVI index. We extend their work by examining the secondary lodging market by using the lodging REITs index. In particular, we investigate the dependence of lodging/resort REIT return behavior over time and document the changing levels of market efficiency. Oak and Andrew (2003) do not test for time-varying efficiency, and instead, consider efficiency as a binary condition. Our paper also addresses this gap in research.

Similar to Zhou and Lee (2013) and consistent with the $\mathrm{AMH}$, we document the time-varying nature of return predictability in lodging/resort REITs, from 1994 to 2016, by using both linear (automatic variance ratio and automatic portmanteau) and nonlinear tests (DominguezLobato test and generalized spectral test). Our research provides clear evidence of deviation from the Martingale, and that profit opportunity existed during specific periods. We see a significant nonlinear dependence in lodging/ resort REITs. Our results, regarding the performance of technical trading rules, show that moving average strategies are superior to buy and hold strategies. Even after adjusting for risk, portfolios that use technical rules have higher Sharpe ratios compared to naïve buy-and-hold portfolios. We consider this as evidence against the market efficiency of lodging/resort REITs. However, according to the AMH in Lo $(2004,2005)$, such opportunities exist for only specific periods, and might not remain available 
to investors because the efficiency of asset returns remain time-varying in nature.

Future research can extend the current strand of literature regarding efficiency by examining individual lodging REITs instead of an index. Since lodging REITs differ in size (market cap), age, institutional ownership, financial characteristics, media coverage, and the number of analysts following the REIT, it can be expected that information dissemination and market reaction may not be similar for all lodging REITs. Similar international studies on developed and emerging lodging markets could add value and assist in a better understanding of this subsector.

\section{Author contributions}

FA was responsible for data collection and analysis. RA and JAH were responsible for data interpretation and writing.

\section{Disclosure statement}

The authors do not have any competing financial, professional, or personal interests from other parties.

\section{References}

Almudhaf, F. (2017). The evolution of return predictability, efficiency, and bubbles in Indonesia. Bulletin of Indonesian Economic Studies (forthcoming).

Barkham, R., \& Geltner, D. (1995). Price discovery in American and British property markets. Real Estate Economics, 23(1), 21-44. https://doi.org/10.1111/1540-6229.00656

Block, R. (2012). Investing in REITs ( $4^{\text {th }}$ ed.). New Jersey: Wiley. https://doi.org/10.1002/9781119202325

Bloom, B. (2009). The predictive ability of historic beta of hotel stocks in the 2008 market downturn. Journal of Hospitality Financial Management, 17(1), 47-61. https://doi.org/10.1080/10913211.2009.10653870

Borde, S. F., Byrd, A. K., \& Atkinson, S. M. (1999). Stock price reaction to dividend increases in the hotel and restaurant sector. Journal of Hospitality \& Tourism Research, 23(1), 40-52. https://doi.org/10.1177/109634809902300104

Brennan, T. J., \& Lo, A. W. (2011). The origin of behavior. The Quarterly Journal of Finance, 1(01), 55-108. https://doi.org/10.1142/S201013921100002X

Cabrera, J., Wang, T., \& Yang, J. (2011). Linear and nonlinear predictability of international securitized real estate returns: a reality check. Journal of Real Estate Research, 33, 565-594.

Case, K. E., \& Shiller, R. J. (1989). The efficiency of the market for single-family homes. American Economic Review, 79, 125137. https://doi.org/10.3386/w2506

Case, K. E., \& Shiller, R. J. (1990). Forecasting prices and excess returns in the housing market. Real Estate Economics, 18(3), 253-273. https://doi.org/10.1111/1540-6229.00521

Charles, A., Darné, O., \& Kim, J. H. (2012). Exchange-rate return predictability and the adaptive markets hypothesis: evidence from major foreign exchange rates. Journal of International Money and Finance, 31(6), 1607-1626. https://doi.org/10.1016/j.jimonfin.2012.03.003

Charles, A., Darné, O., \& Kim, J. H. (2015). Will precious metals shine? A market efficiency perspective. International Review of Financial Analysis, 41, 284-291.

https://doi.org/10.1016/j.irfa.2015.01.018
Choi, I. (1999). Testing the random walk hypothesis for real exchange rates. Journal of Applied Econometrics, 14, 293-308. https:// doi.org/10.1002/(SICI)1099-1255(199905/06)14:3<293::AIDJAE503>3.0.CO;2-5

Dominguez, M. A., \& Lobato, I. N. (2003). A consistent test for the martingale difference hypothesis. Econometric Reviews, 22, 351-377. https://doi.org/10.1081/ETC-120025895

Escanciano, J., \& Lobato, I. (2009). An automatic Portmanteau test for serial correlation. Journal of Econometrics, 151, 140149. https://doi.org/10.1016/j.jeconom.2009.03.001

Escanciano, J., \& Velasco, C. (2006). Generalized spectral tests for the martingale difference hypothesis. Journal of Econometrics, 134, 151-185. https://doi.org/10.1016/j.jeconom.2005.06.019

Fama, E. (1970). Efficient capital markets: a review of theory and empirical work. Journal of Finance, 25, 383-417. https://doi.org/10.2307/2325486

Fama, E. (1991). Efficient capital markets: II. Journal of Finance, 46, 1575-1617. https://doi.org/10.1111/j.1540-6261.1991.tb04636.x

Feng, Z., Price, S. M., \& Sirmans, C. (2011). An overview of equity real estate investment trusts (REITs): 1993-2009. Journal of Real Estate Literature, 19(2), 307-343.

Gatzlaff, D., \& Tirtiroğlu, D. (1995). Real estate market efficiency: issues and evidence. Journal of Real Estate Literature, 3(2), 157-189.

Gau, G. W. (1984). Weak form tests of the efficiency of real estate investment markets. Financial Review, 19(4), 301-320. https://doi.org/10.1111/j.1540-6288.1984.tb00652.x

Gau, G. (1985). Public information and abnormal returns in real estate investment. Journal of the American Real Estate and Urban Economics Association, 13, 15-31. https://doi.org/10.1111/1540-6229.00338

Ghazani, M., \& Araghi, M. (2014). Evaluation of the adaptive market hypothesis as an evolutionary perspective on market efficiency: evidence from the Tehran stock exchange. Research in International Business and Finance, 32, 50-59. https://doi.org/10.1016/j.ribaf.2014.03.002

Gibbons, M. R., Ross, S. A., \& Shanken, J. (1989). A test of the efficiency of a given portfolio. Econometrica, 57, 1121-1152. https://doi.org/10.2307/1913625

Glabadanidis, P. (2014). The market timing power of moving averages: evidence from US REITs and REIT indexes. International Review of Finance, 14(2), 161-202. https://doi.org/10.1111/irfi.12018

$\mathrm{Gu}, \mathrm{Z}$., \& Kim, H. (2003). An examination of the determinants of hotel REITs' unsystematic risk. Journal of Hospitality \& Tourism Research, 27(2), 166-184. https://doi.org/10.1177/1096348003027002002

Hamilton, B. W., \& Schwab, C. (1985). Expected appreciation in urban housing markets. Journal of Urban Economics, 18, $103-$ 118. https://doi.org/10.1016/0094-1190(85)90030-0

Huang, C., Su, H., \& Chiu, C. (2009). REIT market efficiency before and after inclusion in the S\&P 500. Journal of Real Estate Portfolio Management, 15, 239-250.

Jackson, L. A. (2009). Lodging REIT performance and comparison with other equity REIT returns. International Journal of Hospitality \& Tourism Administration, 10(4), 296-325. https://doi.org/10.1080/15256480903202383

Jain, P., Robinson, S., Singh, A. J., \& Sunderman, M. (2017). Hospitality REITs and financial crisis: a comprehensive assessment of market quality. Journal of Property Investment \& Finance, 35(3), 277-289. https://doi.org/10.1108/JPIF-08-2016-0068 
Jang, S., \& Park, J. K. (2011). Hospitality finance research during the recent two decades. International Journal of Contemporary Hospitality Management, 23(4), 479-497.

https://doi.org/10.1108/09596111111129995

Jirasakuldech, B., \& Knight, J. (2005). Efficiency in the market for REITs: further evidence. Journal of Real Estate Portfolio Management, 11, 123-132.

Kim, H., Gu, Z., \& Mattila, A. (2002a). Hotel real estate investment trusts' risk features and beta determinants. Journal of Hospitality \& Tourism Research, 26(2), 138-154. https://doi.org/10.1177/1096348002026002004

Kim, H., Mattila, A. S., \& Gu, Z. (2002b). Performance of hotel real estate investment trusts: a comparative analysis of Jensen indexes. International Journal of Hospitality Management, 21(1), 85-97. https://doi.org/10.1016/S0278-4319(01)00026-3

Kim, J., \& Jang, S. (2012). Comparative analysis of hotel REITs: examining risk-return and performance characteristics. International Journal of Contemporary Hospitality Management, 24(4), 594-613. https://doi.org/10.1108/09596111211226842

Kim, J. H. (2009). Automatic variance ratio test under conditional heteroscedasticity. Finance Research Letters, 6, 179-185. https://doi.org/10.1016/j.frl.2009.04.003

Kim, J. H., Shamsuddin, A., \& Lim, K. (2011). Stock return predictability and the adaptive markets hypothesis: evidence from century-long US data. Journal of Empirical Finance, 18, 868-879. https://doi.org/10.1016/j.jempfin.2011.08.002

Kim, S., H., Kim, W. G., \& Hancer, M. (2009). Effect of IT investment announcements on the market value of hospitality firms using event study methodology. Tourism Economics, 15(2), 397-411. https://doi.org/10.5367/000000009788254304

Kim, W. G., Jackson, L., \& Zhong, J. (2011). Performance comparison of lodging REITs, hotel C-corporations and resorts, and casinos. Tourism Economics, 17(1), 91-106. https://doi.org/10.5367/te.2011.0023

Kleiman, R., Payne, J., \& Sahu, A. (2002). Random walks and market efficiency: evidence from international real estate markets. Journal of Real Estate Research, 24, 279-297.

Koh, Y., \& Lee, S. (2013). Stock market reactions to US hotel firms' strategic alliances. Tourism Economics, 19(2), 373-391. https://doi.org/10.5367/te.2013.0210

Kuhle, J., \& Alvayay, J. (2000). The efficiency of equity REIT prices. Journal of Real Estate Portfolio Management, 6, 349-354.

Kummerow, M., \& Lun, J. C. (2005). Information and communication technology in the real estate industry: productivity, industry structure and market efficiency. Telecommunications Policy, 29, 173-190. https://doi.org/10.1016/j. telpol.2004.12.003

Lee, S., \& Connolly, D. J. (2010). The impact of IT news on hospitality firm value using cumulative abnormal returns (CARs). International Journal of Hospitality Management, 29(3), 354362. https://doi.org/10.1016/j.ijhm.2009.08.007

Liu, C. H., \& Mei, J. (1992). The predictability of returns on equity REITs and their co-movement with other assets. The Journal of Real Estate Finance and Economics, 5(4), 401-418. https://doi.org/10.1007/BF00174808

Liu, P. P. (2010). Real estate investment trusts: performance, recent findings, and future directions. Cornell Hospitality Quarterly, 51(3), 415-428. https://doi.org/10.1177/1938965510370732

Lo, A. (2004). The adaptive markets hypothesis: market efficiency from an evolutionary perspective. Journal of Portfolio Management, 30, 15-29. https://doi.org/10.3905/jpm.2004.442611

Lo, A. (2005). Reconciling efficient markets with behavioral finance: the adaptive markets hypothesis. Journal of Investment Consulting, 7, 21-44.
Manning, C., O’Neill, J. W., Singh, A. J., Hood, S., Liu, C., \& Bloom, B. A. (2015). The emergence of hotel/lodging real estate research. Journal of Real Estate Literature, 23(1), 1-26.

Mar-Molinero, C., Menéndez-Plans, C., \& Orgaz-Guerrero, N. (2017). Has the 2008 financial crisis changed the factors determining the systematic risk of shares in the "European Hospitality Industry"? (2003-2013). Journal of Hospitality and Tourism Management, 31, 59-69. https://doi.org/10.1016/j.jhtm.2016.10.002

McIntosh, W., \& Henderson, G. Jr. (1989). Efficiency of the office properties market. The Journal of Real Estate Finance and Economics, 2, 61-70. https://doi.org/10.1007/BF00161717

Oak, S., \& Andrew, W. (2003). Evidence for weak-form market efficiency in hotel real estate markets. Journal of Hospitality \& Tourism Research, 27(4), 436-447.

https://doi.org/10.1177/10963480030274004

Payne, J. E. (2006). Further evidence of the transmission of shocks across REIT markets: an examination of REIT subsectors. Applied Financial Economics Letters, 2(3), 141-146. https://doi.org/10.1080/17446540500447629

Payne, J. E., \& Waters, G. A. (2007). Have equity REITs experienced periodically collapsing bubbles? The Journal of Real Estate Finance and Economics, 34(2), 207-224. https://doi.org/10.1007/s11146-007-9007-0

Rayburn, W. B., Devaney, M., \& Evans, R. D. (1987). A test of weak-form efficiency in residential real estate returns. AREUEA Journal, 15, 220-233. https://doi.org/10.1111/1540-6229.00429

Ro, S., \& Ziobrowski, A. J. (2011). Does focus really matter? Specialized vs. diversified REITs. The Journal of Real Estate Finance and Economics, 42(1), 68-83. https://doi.org/10.1007/s11146-009-9189-8

Serrano, C., \& Hoesli, M. (2010). Are securitized real estate returns more predictable than stock returns? The Journal of Real Estate Finance and Economics, 41, 170-192. https://doi.org/10.1007/s11146-008-9162-y

Schindler, F., Rottke, N., \& Fuss, R. (2010). Testing the predictability and efficiency of securitized real estate markets. Journal of Real Estate Portfolio Management, 16, 171-191.

Schindler, F. (2011). Market efficiency and return predictability in the emerging securitized real estate markets. Journal of Real Estate Literature, 19, 111-150. https://doi.org/10.2139/ssrn.1622720

Simon, H. (1955). A behavioral model of rational choice. Quarterly Journal of Economics, 69, 99-118. https://doi.org/10.2307/1884852

Simon, H. (1982). Models of bounded rationality (Vols. 1 and 2). Cambridge, MA: MIT Press.

Su, J., Cheung, A., \& Roca, E. (2012). Are securitized real estate markets efficient? New international evidence based on an improved automatic portmanteau test. Economic Modelling, 29, 684-690. https://doi.org/10.1016/j.econmod.2012.01.015

Tang, C. H., \& Jang, S. (2008). The profitability impact of REIT requirements: a comparative analysis of hotel REITs and hotel C-corporations. International Journal of Hospitality Management, 27, 614-622. https://doi.org/10.1016/j.ijhm.2007.07.026

Urquhart, A., \& Hudson, R. (2013). Efficient or adaptive markets? Evidence from major stock markets using very long run historic data. International Review of Financial Analysis, 28, 130-142. https://doi.org/10.1016/j.irfa.2013.03.005

Wang, Z. (2004). Dynamics of urban residential property prices - a case study of the Manhattan market. The Journal of Real Estate Finance and Economics, 29(1), 99-118. https://doi.org/10.1023/B:REAL.0000027203.12175.90 
Wheaton, W. C., \& Rossoff, L. (1998). The cyclic behavior of the US lodging industry. Real Estate Economics, 26(1), 67-82. https://doi.org/10.1111/1540-6229.00738

Yen, G., \& Lee, C. (2008). Efficient market hypothesis: past, present, and future. Review of Pacific Basin Financial Markets and Policies, 11, 305-329.

https://doi.org/10.1142/S0219091508001362

\section{Appendix}

Table A1. Constituent companies of the FTSE NAREIT Lodging/Resort REITs Subsector Index (source: Feng et al. (2011) updated. http://www.mckayprice.com/EREIT_List_93-15.xlsx)

\begin{tabular}{|l|c|c|c|}
\hline \multicolumn{1}{|c|}{ Company_name } & ticker & $\begin{array}{c}\text { year_ } \\
\text { enter }\end{array}$ & $\begin{array}{c}\text { year_ } \\
\text { exit }\end{array}$ \\
\hline Wetterau Properties, Inc. & WTPR & 1993 & 1994 \\
\hline Banyan Hotel Investors Fund & VHT & 1993 & 1995 \\
\hline Starwood Hotels \& Resorts & HOT & 1993 & 1999 \\
\hline RFS Hotel Investors, Inc. & RFS & 1993 & 2003 \\
\hline Jameson Inns, Inc. & JAMS & 1994 & 2003 \\
\hline Equity Inns, Inc. & ENN & 1994 & 2007 \\
\hline Innkeepers USA Trust & KPA & 1994 & 2007 \\
\hline Winston Hotels & WXH & 1994 & 2007 \\
\hline FelCor Lodging Trust Inc. & FCH & 1994 & \\
\hline Wyndham International, Inc. & WYN & 1995 & 1998 \\
\hline Sunstone Hotel Investors, Inc. & SSI & 1995 & 1999 \\
\hline Hospitality Properties Trust & HPT & 1995 & \\
\hline $\begin{array}{l}\text { American General Hospitality } \\
\text { Corporation }\end{array}$ & AGT & 1996 & 1998 \\
\hline Host Funding, Inc. & HFD & 1996 & 1998 \\
\hline Boykin Lodging Company & BOY & 1996 & 2006 \\
\hline Humphrey Hospitality Trust, Inc. & HUMP & 1997 & 2005 \\
\hline $\begin{array}{l}\text { Patriot American Hospitality, } \\
\text { Inc. }\end{array}$ & PAH & 1998 & 1999 \\
\hline Meditrust Companies, The & MT & 1998 & 2001 \\
\hline InnSuites Hospitality Trust & IHT & 1998 & 2004 \\
\hline Host Marriott & HMT & 1998 & 2006 \\
\hline MeriStar Hospitality Corporation & MHX & 1998 & 2006 \\
\hline LaSalle Hotel Properties & LHO & 1998 & \\
\hline Hersha Hospitality Trust & HT & 1999 & \\
\hline La Quinta Properties, Inc. & LQI & 2001 & 2003 \\
\hline & & & \\
\hline
\end{tabular}

Zhou, J., \& Lee, J. M. (2013). Adaptive market hypothesis: evidence from the REIT market. Applied Financial Economics, 23(21), 1649-1662. https://doi.org/10.1080/09603107.2013.844326

\begin{tabular}{|l|c|c|c|}
\hline \multicolumn{1}{|c|}{ Company_name } & ticker & $\begin{array}{c}\text { year_ } \\
\text { enter }\end{array}$ & $\begin{array}{c}\text { year_ } \\
\text { exit }\end{array}$ \\
\hline Ashford Hospitality Trust & AHT & 2003 & \\
\hline Strategic Hotel Capital, Inc. & SLH & 2004 & 2006 \\
\hline $\begin{array}{l}\text { Eagle Hospitality Properties } \\
\text { Corporation }\end{array}$ & EHP & 2004 & 2007 \\
\hline $\begin{array}{l}\text { Highland Hospitality } \\
\text { Corporation }\end{array}$ & HIH & 2004 & 2007 \\
\hline Sotherly Hotels, Inc. & SOHO & 2004 & \\
\hline Sunstone Hotel Investors, Inc. & SHO & 2004 & \\
\hline Supertel Hospitality, Inc. & SPPR & 2005 & 2015 \\
\hline $\begin{array}{l}\text { DiamondRock Hospitality } \\
\text { Company }\end{array}$ & DRH & 2005 & \\
\hline Strategic Hotels \& Resorts & BEE & 2006 & 2015 \\
\hline Host Hotels \& Resorts & HST & 2006 & \\
\hline Pebblebrook Hotel Trust & PEB & 2009 & 2010 \\
\hline Chatham Lodging Trust & CLDT & 2010 & \\
\hline Chesapeake Lodging Trust & CHSP & 2010 & \\
\hline Pebblebrook Hotel Trust & PEB & 2011 & \\
\hline RLJ Lodging Trust, Inc. & RLJ & 2011 & \\
\hline Summit Hotel Properties, Inc. & INN & 2011 & \\
\hline $\begin{array}{l}\text { Ryman Hospitality Properties, } \\
\text { Inc. }\end{array}$ & RHP & 2012 & \\
\hline Ashford Hospitality Prime, Inc. & AHP & 2013 & \\
\hline InnSuites Hospitality Trust & IHT & 2013 & \\
\hline Apple Hospitality REIT & APLE & 2015 & \\
\hline Condor Hospitality Trust, Inc. & CDOR & 2015 & \\
\hline Xenia Hotels \& Resorts Inc. & XHR & 2015 & \\
\hline
\end{tabular}

